\title{
AND THE MACHINE BECAME FLESH AND DWELT AMONG US: REFIGURING THE NEW HUMAN IN KAROL WOJTYLA'S CHRISTIAN PERSONALISM
}

\author{
Alma S. Espartinez \\ De La Salle-College of St. Benilde, Philippines
}

\begin{abstract}
This paper explores refiguring the concept of a new human proposed by transhumanism in light of Karol Wojtyla's Christian Personalism. I start by presenting the tenets of transhumanism, focusing on the prospect of enhancing humans into posthuman persons to redesign human nature. After that, I position Karol Wojtyla's Christian personalism vis-à-vis transhumanism into a conversation in an attempt to examine the ethical implications of human enhancement from the personalist concept of the person inquiring into the problematic moral issues arising from the ethics of enhancement. Drawing some ethical insights from these investigations, I conclude that human enhancement intervention is morally problematic and reprehensible because of its attempt to redesign the human species, make a mockery of human dignity and create a posthuman that is no longer human. While human enhancement will endure in the deep future, it is our moral response to these significant changes that are now in question. This discussion on transhumanism is enormously significant as an important contemporary intellectual discourse as it offers an unsettling possibility of moving the humans over and making machines take charge.
\end{abstract}

\section{INTRODUCTION}

What if you are to celebrate your $250^{\text {th }}$ birthday and you still feel stronger than ever, with your mind still lucid and your human body still so resilient you only feel 40 ? Years back, human life spanning beyond its natural limits, say 120 years or more, was a long way off. In this age of biotechnology, however, where the line between the human body and machine is removed (Kurzweil 2006), living beyond the average life expectancy will soon become the new (ab)normal (de Grey 2003). William Gibson (2003) confidently thinks the future is already here; in fact, it is already well underway! Truly, technological advancement has intensely redefined and refigured what it means to be human.

As technology gets more complex, the capacity of homo sapiens to perform tasks has been dramatically enhanced by highly sophisticated technological supports 
such as robotic implants, artificial retinas, and prosthetics. Some now have chips in their head to make them more skillfully advanced. Machines work alongside humans as their assistants and enhancers. Our friends are robots - half-human and halfmachine, which are considered transhumans. Now, parents can choose the gender of their children. Bio-enhancers edit embryos to essentially force genetic changes onto future generations. We now insert smart skin - an ultrathin, electronic patch with the mechanics of human skin, under the wrist for electromyography and other vital measurements. Soon, we will have self-fixing robots. It is no wonder that transhumanist Neil Bolstrom (2011) predicts that in 2045 we will achieve electronic immortality that will make us live forever and ever!

At this point of human-machine coalescence, with all these prosthetics and microchips implanted inside our bodies, will these future human beings exceeding natural human limits still be called human? If we continuously replace bits of the human body that wear out or go wrong, if inorganic parts merge with organic parts such as the bionic limbs that have tremendously greater capacity and flexibility than the traditional limbs of homo sapiens, would these electronic humans still be part of the human species? How invasive should implants be for someone to be considered a cyborg? Up to which point, at which we enhance, is partly natural and partly artificial, are we still recognizably human? Is there some speciation point in which we cease to exist being human, and becoming a posthuman, or non-human, entirely? Where is all this taking us?

\section{TRANSHUMANISM FOR A WHOLE NEW WORLD}

Transhumanism, abbreviated as $h+$ (humanity plus), is a movement that envisions a happier, brighter, smarter, and longer life for humans by developing cutting-edge technologies to significantly enhance the intellectual, physical, and psychological existence beyond its fundamental natural human form and limitation. It promises "wonderful and exceedingly worthwhile human conditions" (World Transhumanist Association 2002), far surpassing the threshold of our wildest imagination. Years from now, we would close the gap as we transition from fictional science-based films - Robocop, Ex Machina, Bicentennial Man, and Alita - to the altered reality of cyborgs. Sooner, a new class of augmented humans will be created outplaying, outsmarting, and outlasting the unaugmented ones.

One future day, humans will be immensely more physically powerful, more mentally skillful, and more than human. As transhumanists envision what is forthcoming with the aid of enhancement biologists, their creed is to create a posthuman species that is no longer human. In general, transhumanism dreams of exceeding God's creation by remaking the world, producing species sans genetic defects and human failings. It will fix what God, in creating this world He thought was good, failed to fix. In what follows, I outlined what transhumanists ideally and fearfully want to achieve.

\section{AIM FOR PERFECTION VIA TECHNOLOGICAL DESIGN}

Transhumanists claim that our human nature is genetically deficient, 
pathetically weak, and aesthetically dysteleological. Worse, the human body is a "deathtrap" (Bostrom 2008, 3), a forfeitable nuisance (Onishi 2011), something manipulable, replaceable, and disposable. Because of this inherent defect, the transhumanists propose to redesign human nature according to a set of desired human genetic programming, transcending from their viewpoint God's awfully inadequate creation. Enlightened scientists, they believe, can do better than this Intelligent Creator. There is no such thing as fixed and determined human nature because the human gene pool is not static; in fact, it should - and it must - be radically altered to make humans better than what they are now. The human body that the person inhabits is the locus of immense human transformation, lurking silently for its liberation from its imprisonment from the human person. Persons, transhumanists maintain, are not a substance but the unity of lived-through advanced technological experiences.

Given this template for the future human, people should be given a broad discretion over which morphological freedom they want to use (Sandberg 2013), such as giving them the choice of using regenerative and nano-medicine replacing healthy human organs with artificial and "superior ones." Illness, aging, and death are monstrous viruses that need to be eliminated. All life-preserving and life-extending technologies should be embraced, affirmed, and endorsed. When a new design for humanity is accomplished, we will recover our lost paradise. So claimed the transhumanists.

\section{MAKE HUMAN EXTINCT}

For transhumanists, the aim for perfection via technological design necessitates self-annihilation. They claim that our cosmos needs to be ready for a technological singularity, an event where real artificial intelligence (AI) surpasses human intelligence, making humans extinct. Kurzweil (2006) sees "singularity" as technological progress creating a revolution in human life so deep it is a disruption from what we had before. This singularity propels the path towards the aversion to, and elimination of, the human body. It is a favorable time when machines will take flesh and dwell among us humans. Our human bodies, our human brains, and the machines will one day in the near future, as Kurzweil predicts, merge into a single immense collective intelligence. In a blink of an eye, these machines becoming flesh will take us over. Given this prediction, we would find ourselves relinquishing our authority to machines through the constant progress of science. It will not be far behind; it is coming near.

Transhumanists believe that human nature is genetically deficient and miserably flawed in need of fixing into something better-than-human. Transhumanists, as Wareham writes, "advocate(s) the desirability of making people 'better than well"" (2016, 522). Something has to be done to make us genomically attractive. With the unqualified gifts of human enhancement Bostrom unhesitatingly claims that "we shall eventually manage to become posthuman, beings with vastly greater capacities than present human beings have" $(2003,493)$. This line of thinking is echoed by Naam when he wrote, "the drive to alter and improve on ourselves is a fundamental part of who we humans are. As a species we have always looked for ways to be faster, 
stronger, and smarter and to live longer" $(2005,9)$. This project, transhumanists claim, is scientifically admirable worthy of collective support.

To conclude this section, let me emphasize the transhumanist creed: celebrate genetic enhancement and make humans extinct! Genetic manipulation, especially that which may alter human physiology, longevity, intellectual and emotional life, is not only morally acceptable and ethically right, as Checketts argues, but is even morally obligatory that it should be made available for individuals and human species, in general, to attain self-advancement in any way possible $(2018,114)$. Soon, humans will be rendered useless.

In the succeeding sections, I will present the arguments against transhumanism, particularly those promoted by Karol Wojtyla, who is viewed as the forerunner of Christian Personalism.

\section{CHRISTIAN PERSONALIST'S RESPONSE TO TRANSHUMANISM}

As the saga of personalism-transhumanism debates heats up, the one question that remains contentious is how the human person is viewed and understood. The personalist approach to the person has at its focus the whole personal reality. As it is, Christian personalism, which questions the normative propriety of bodily intervention, stands as the censure of transhumanist thoughts. The crucial argument leveled against transhumanism is that it refigures the human species, violates human dignity, and denigrates what it means to be human.

Wojtyla, deeply alarmed by the reduction and reification of the human person in both theory and practice, insisted that an anthropological analysis be refocused on what is irreducible in the human person, on what is primordially or essentially human, on what constitutes the entire originality of human person in the world (1978, 107-114). The person is a human being in his unique and unrepeatable individuality with pre-eminent dignity and whose life is sacred and must be treated with reverence. It follows as strictly necessary that he be bestowed with utmost respect according to his incommensurable values as a human person: his non-utilitarian value, that he cannot be an object of experimentation, and his personalistic value, that he possesses a value precisely as a human person (John Paul II 1981). These are the person's non-negotiable values.

My main objective in this section is to show, from the Christian Personalist's perspective, that (1) human enhancement is an attack against human dignity and what it means to be human; (2) there is an inherent relationship that exists between the person and the human body that is revelatory of the essential meaning of the person; and (3) transhumanism is wishful thinking.

\section{IRREDUCIBILITY OF THE HUMAN PERSON}

Wojtyla is specifically concerned with articulating "subjectivity in the personal sense" through a description of personal experience. Using the traditional and phenomenological concepts of the person, Wojtyla established a philosophical anthropology, which sees the human person in his concrete and integral totality, in his unique, personal subjectivity that leads to the understanding of what is primordially 
and irreducibly human. Defined as a rational animal, the human person has lived experiences that are uniquely his own. The human person, in Wojtyla's Christian personalism, is unique and unrepeatable. This structural incommunicability unfolds the fullness of man's subjectivity. Freedom and self-determination manifest the transcendence of the person in his action. Man is free insofar as "he depends chiefly on himself for the dynamization of his own subject" (Wojtyla 1979, 120), devoid of any biological enhancement that does not necessarily connect with the essence of the person.

Wojtyla's philosophy views the human person as a unity of body and spirit, making him a spiritual, free, and rational being made in God's image. As a spiritualized body, the human body is irreducible to mere matter. Understood this way, significant enhancement employed to the human body without considering its spiritual dimension is a violation of the divine design and the inherent dignity invested in the human person (John Paul II 1994, n. 19). The mystery of the Incarnation speaks of a God who chooses to dwell among us by appearing in the flesh in order to redeem the flesh (Labrecque 2017). In The Acting Person, Wojtyla (1979) highlighted the inherent correlation between the person and the human body by stating that the person reveals himself through his actions expressed by the human body. Revelatory of the human person, the "body determines man's ontological subjectivity and participates in his dignity as a person." (John Paul 2006, 45) Wojtyla argued that the transhumanists' failure to recognize this inherent dignity of the human body in relation to the human person is a desecration of the human person and ultimately of God, who is its Creator.

The fiercest resistance to human enhancement concerns its effect on the human person and what it means to be human (Sandel 2007). Transhumanism views human nature and human dignity as anathema to biotechnological evolution, restricting the future glory it can offer to humanity. Here transhumanists view human dignity more in terms of human rights rather than human duties. In his Theology of the Body (1997) and echoed in his Evangelium Vitae (1995), St. John Paul II emphasized that "all of man's bodily life is also the life of the soul, possessed of a supernatural dignity and a vocation to union with God." Therefore, altering and enhancing the human condition at will by transgressing the genetic boundaries, such as defying our natural built-in limit, is in every case utterly unacceptable and downright insulting. Wojtyla is not against technological advancement; what he is against is the radical enhancement that breaches the borderlines of personhood and deforms human nature. He maintains that failing to see the meaning of human being as a moral concept with its rich normative content fails to grasp human dignity and, even more so, the meaning of what it means to be human.

The analysis of the essential relation of the body to the person prevents us from treating the body, owing to its inherent and constitutive value, as a machine that can be manipulated for one's own purpose. If the body is a machine, then it can be owned, bought, sold, rented, repaired, removed, and supplemented (Hogan \& Levoir 1985). Biotechnology nullifies my personhood and renders me absent from myself. The reduction of the body to a biological machine exposes us to certain dangers whose consequences must not be underestimated.

Understood in this framework that the body is related to the person inasmuch as through the body the person is expressed, the body should also be the means of the person's expression of one's interiority. Only in this light can we have a clear grasp of the value of the human body as purposely designed in its relation to the person, and 
so grounds Wojtyla's claim against dehumanization via radical enhancement. As Pope Francis lucidly pointed out in Christus Vivit, "(t)he capacity to intervene in DNA, the possibility of inserting artificial elements into organisms (cyborgs) and the development of the neuroscience represent a great resource, but at the same time, they raise serious anthropological and ethical questions" $(2019,82 ; 2018,37)$. When the person acts out of biological enhancement, he is not really acting because he is not acting freely. As such, the dynamism at the level of artificiality is in opposition to the dynamism at the level of the person. The technological advancements proposed by transhumanists aim to reduce all material entities to patterns of information in order to have the freedom to arrange and re-arrange them at an anatomical level (Onishi 2011, 101-112). This is tramping a dangerous anthropological trail that is inimical to the inherent nature and dignity of the human person.

Wojtyla's emphasis on the transcendence and freedom of the human person and the self-determining nature of human acts provide a further sense of human dignity: human acts shape personhood, and the shape that one's life takes need not be determined by external forces such as biomedical technology. Human persons, created in the image of God, pursue the good through the use of intellect, and fulfill themselves in accordance with the moral order. This shows that human nature is clearly purposeful, and transhumanism cannot dismiss it as dysteleological.

\section{HUMAN BODY IS NOT UNDER REPAIR}

As transhumanism attracts greater attention and lures us of its ideals of a great future, I now examine the connection between the human body and technology and how the connection changed over time.

Transhumanism tends to view physical deformities as an inferior state and as a personal misfortune (Thomson 2017), evoking feelings of sympathy and pity. Disability becomes, for the transhumanists, a personal issue. The worth of the disabled is viewed as something below the threshold of what is considered "normal," and the desire to measure up to cultural standards for one's worth to avoid the stigma attached to being less than human becomes for them an ever-present struggle. Will the disabled be objects of communal disgust?

We argue that we have God-given nature, goals, and limits in life such that being able to lift $750 \mathrm{lbs}$. over one's head or making the person lives to age 888 is extremely unnatural and in violation of natural human strength. To tamper with human nature or adjust the human person through any form of biotechnological enhancement - such as consciousness uploading, human cloning, embryonic stem cell - is to cheapen the human person and forfeit human virtue and flourishing. Christian personalism insists that anything that violates human dignity must be eschewed. Anything that safeguards and promotes human dignity must be endorsed. The human body is not under repair.

I firmly argue that our human dignity entails embracing our embodiment and its inherent limits and honoring such limitations as part of our facticity. Defying this boundary through biological enhancement means challenging the limits intrinsic to the human person and hence to human dignity. Wojtyla speaks of personal growth (selffulfillment), not by transcending our current biological limits but through our human 
actions expressing self-determination, self-possession, and self-governance. With cyborgs around, aren't their actions dependent on machine-learning algorithms? Are the actions of cyborgs the act of the machine or the act of the person, or are they already human-machine actions? Embedding microchips into the human person creates a concern on personal identity as this may translate into a substantial advantage for the enhanced person. For Wojtyla, it is the moment of efficacy, not an artificial enhancement, that gives the superior performance its dignity.

\section{HUMANS WILL BE HUMANS}

Setting standards of perfection would not be possible if limitless power did not matter to us; and because all these desires for perfection mean the world to some, if not for most of us, insatiability would be one of the ambivalent possibilities in genetic advancement - trying to perfect what it disdains. "Defining personhood and estimating one's value based on utility and function," Labrecque declares, "disqualify those who do not, cannot, will not, or are no longer able to operate at a level that is considered contributive (by whom and to what end are not always clear)" (Labrecque, 2017, 165).

What do we want to keep, and what are we willing to lose? What do we consider as moral human development, and what enhancement do we reject as offensive to the person we are? Designing a baby obviously constitutes a violation of human dignity that is applied to the technique of genetic selection that involves killing a human being, or treating a human being as a means to the ends of others, or predetermining the characteristics of a human being. Made-to-order babies are tantamount to depriving if not denying - the children an open future, "impairing and violating their right to choose their life plan for themselves (Sandel 2007, 7) and to weave their future possibilities. Clearly, these bio-technological advancements desecrate our humanity.

A disease should not be regarded as a genetic scandal, as some transhumanists seem to think it is. Aging provides the opportunity to embrace our vulnerability. Pain and suffering are human realities that allow us to speak of God in the midst of human grief. Fortitude, hope, and transcendence - these are all attributed to the fundamental dignity of human personhood. I refuse to romanticize human mortality and fallibility, but without pain, how would you know happiness? Without death, how would you appreciate life? It is human facticity, fallibility, and contingency that make human excellence truly honorable and profoundly meaningful. Limits to human capacity should be carefully observed and respected rather than heedlessly trespassed and ignored. Immortality, assured to us by the transhumanists if we allow ourselves to be biologically modified, trivializes life's meaning-making as it makes human existence scientific rather than existential, biological rather than experiential, material rather than spiritual. Bernard Williams, though recognizing that death is dreadful and therefore an anguished fear to be evaded and averted, held that an immortal life free from the prospect of death does not make sense (1973). To be human and not die is a metaphysical mistake; this is tantamount to abandoning our very humanity. Only the mortal and the vulnerable are truly courageous, tenacious, and resilient, for they know fully well that life is not forever. Immortals can never be martyrs!

Let the transhumanists do whatever they want to do with their science-enabled 
engineering! But do not touch us, humans. Improve us, yes, but do not change the natural way we are. Look at some people who have succeeded despite genetic deficiencies: Albert Einstein, Abraham Lincoln, Charles Darwin, Thomas Edison, to name a few. Were they radically enhanced? As human beings, we are broken, unhappy, scared, heartbroken, sick - but despite all these, we still get by. Let us also stop looking for a perfect design for humans; we are all born imperfect, and we will all stay that way. If we were perfectly designed, then there would be no human drama. The nature of drama is to wait for the meaning to unfurl. If we surrender to transhumanists' impulses, we humans might not be able to handle the overwhelming power we bestow on a machine, and it will take off - and take over. We make technology; let us not allow technology to make us.

\section{TRANSHUMANISM IS WISHFUL THINKING}

In no ambiguous terms, radical transhumanists express their goal of seeking the disposability of the human body towards human extinction. Dmitri Itskov, the Russian entrepreneur and founder of 2045 Initiative, proposes "the creation of optimate conditions promoting the spiritual enlightenment of humanity; and the realization of a new futuristic reality based on five principles: high spirituality, high culture, high ethics, high science and high technologies" (2045.com; emphasis mine). In my honest evaluation, all these transhumanist ideals are the height of human possibilities at its best, a moral scam at its worst. Transhumanism becomes a victim of its own success. We do believe in technological progress in the sense that the material conditions are much better now than they were during the Neanderthal period. However, will transhumanists be successful in creating a posthuman? Are their fanciful ambitions realistic, feasible, and sustainable in the future? More importantly, would the future they envisioned socially and morally acceptable? Tom Koch mentioned, and I concur with him, that "the supposedly scientific basis on which transhumanist promises are built is critiqued as futurist imaginings with little likelihood of actualization" (2020, 179). It is wishful thinking and pure speculation, promising and threatening to remake the world! Transhumanist aspirations generate doubts, a beguiling mix of fantasy and deceit, even from among transhumanists, about moving the humans over and making machines take charge.

Transhumanists go beyond therapy; they go for radical enhancement. It is fashioning better people for a better world. Any resistance to techno-innovation appears regressive, outmoded, and insular. The next stage is enhancing evolution - machines are dwelling with humans replacing flesh with steel and silicon imbued with immortality. Homo sapiens will one day become "more than human," seeking the next day to become God. In order to expose its beguiling agenda about human nature, it bears repeating that transhumanism is about enhancing sometimes, replacing often, and destroying always. Isn't this premonition of imminent danger to humanity unsettling and unnerving?

\section{WHAT AWAITS US IN THE DEEP FUTURE?}

The issue is not about how one should feel about mechanized humans but about 
the kind of self that transhumanism makes possible today. Subliminally now but knowingly soon, we will be experiencing what Giorgio Agamben (1999) called "bare life," an existence devoid of a sense of dignity, a life of human desperation stripped of self-sufficiency, highlighting the disgrace of losing being human. This will be the contour our humanity will assume in the very near future as we become mechanized, information-tech suave, and neuro-tech deferential. Bare life as opposed to an authentic life. Is there still anything we might all get dismayed about together anymore? I am afraid there is none because the prospects for a world permanently without a concept of a 'line' is scary.

When it comes to the biological integrity of the human body, Wojtyla makes it clear that as imago Dei, endowed with rationality and the ability to use our power in godly ways, we are also entrusted with a more significant share of stewardship. As stewards, we must safeguard the "living totality" of the human body, maintaining ordinary functioning and avoiding tampering, whether through genetic manipulation or biological enhancement. Called as particeps creatoris, we are demanded to use technologies in ways that preserve the whole order of nature, the human body included. As man understands and rationally accepts the order of nature by following its laws, the human person exhibits most fully his value as a person.

The transhumanists maintain that moral questions arising from human genetic enhancement must be treated as ethically indifferent and detached from questions about whether such alteration leads to the creation of a new human. John Harris, another avid transhumanist, argues that "if the gains were important enough (sufficiently beneficial) and the risks acceptable, we would want to make the relevant alterations...we would have an obligation to make such changes" $(2010,37)$. Let this be clear: there is nothing wrong with technology. We want to promote the use of technology in a way that promotes human flourishing. Human improvement is the order of the day. However, we want, as Christian personalists insist, to maintain the dignity of an unaltered and unaugmented human person.

The purpose of this paper is to bring learned and thoughtful Christian thinkers, philosophers, policy-makers into dialogue with the transhumanists to study some prospects for rapprochement. Wojtyla's concept of the human person and that of the augmented body are divided by an uncomfortable hostility between two metaphysics. For the transhumanists, the promise of a better future needs the modification of the human genetic blueprint; for Wojtyla, there is glory in the flesh, and that we cannot cease to be human, surpass human and destroy human.

Are we necessarily the end of the line of adaptation? Will machines kill off the human species? Actually, being wiped clean off the earth is not our fear. Our fear is that we make a mockery of the human nature God has designed it to be. The future is not about machines or robots or AIs as such; it is about the kind of life we want to live and the kind of world we want to have. C.S. Lewis warned of a future in which "man's final conquest has proved to be the abolition of man" (1943, no page). Such a dark scenario in the deep future will never come to pass if we refuse to pass the torch of evolution to our digital successors and fade into oblivion.

Further, can we still talk of the human community here and through participation based on the common good? What common good can transhumanism talk about? The human person is stripped of his capacity to experience his humanness because robots 
cannot be spoken of as an "authentic other I." Humans are social in their essence. Participation is an expression of self-fulfillment of the person that is realized in society. The human person is regarded as relational as expressed through his body by the discovery of his being alone "in the visible world." participation, according to Wojtyla, aims "to specify and express what it is that safeguards us as persons along with the personalistic nature and value of our activity as we exist and act together with others in different systems of social life" $(1979,201)$. Due to man's capacity to participate in the very humanity of the other, every human being can be our neighbor. Wojtyla argues that the "moral responsibility produced by my insight into the subjectivity of the other allows me to see in the other a share in the same personal dignity I recognize in myself' $(1979,201)$.

\section{CONCLUSION: HONOR THY NATURE}

From our previous discussion, I showed that transhumanism is a heady mix of dangerous themes: perilous game, existential risk, dehumanization, and annihilation. For decades now, it has taken its toll on our humanness; it has leeched our humanity from us. In order to flourish as humans, transhumanism has inculcated in our thoughts that the human body, owing to its flawed human condition, necessitates all these biotechnological interventions. This transhumanist position paints a narrow perspective of our corporality and finitude. Running to the rescue, Christian personalism, with Wojtyla as its main advocate, argues that understanding human dignity implies an appreciation of our human nature.

Transhumanists' dream demands serious engagement with moralists and ethicists. Transhumanism does not discuss prophecies; it only presents possibilities. Moreover, if we do not like these possibilities, we need to do something about it. For Wojtyla, our creation in the image and likeness of God, our capacity for vertical transcendence, our self-fulfillment in and through human acts reveal our human nature as possessing a dignity beyond compare. Let us not be deceived by the transhumanists' promise of a better and healthier world for better and healthier people. All this is an empty promise meant to defraud us if we are gullible enough to believe them. In strong terms, transhumanist's position is purely selfish, revealingly atheistic, and abysmally duplicitous.

In his Sign of Contradiction, Pope John Paul II mentioned that human dignity had been so compromised we no longer understand that we are made in the image of God (1979, 32-33.) The Word became flesh and dwelt among us to recover that truth and raise humanity to dignity befitting human being qua human. Let us not surrender our humanity. Let us not give up on ourselves. Let us not allow this machine to take flesh and take charge. Either we speak up now, or we connive with it. Optimistically speaking, the future will not be up to cyborgs; it will still be up to us - humans.

\section{REFERENCES}

Agamben, Giorgio. 1999. Remnants of Auschwitz: the witness and the archive. Zone books. 
“About Us, 2045 Initiative.” 2014. Strategic Social Initiative. http://2045.com/about/. Bostrom, Nick. 2003. Human genetic enhancements: a transhumanist perspective. The Journal of value inquiry 37(4):493-506. https://doi.org/10.1023/B:INQU.0000019037.67783.d5.

Bostrom, Nick. 2008. Letter from utopia. Studies in Ethics, Law, and Technology 2(1). https://doi.org/10.2202/1941-6008.1025.

Bostrom, Nick. 2011. In defense of posthuman dignity. Transhumanism and its critics. Edited by G. R. Hansel and W. Grassie. Philadelphia, PA: Metanexus.

Checketts, Levi. 2018. Homo gubernator: a moral anthropology for new technologies. Graduate theological union.

de Grey, Aubrey D. N. J. 2003. The foreseeability of real anti-aging medicine: Focusing the debate. Experimental gerontology 38:927-934. https://doi.org/10.1016/S0531-5565(03)00155-4.

Francis, Pope. "Final Document of the Fifteenth Ordinary General Assembly of the Synod of Bishops, 8."

Gibson, William. 2003. The future is already here-it's just not evenly distributed. The Economist 4.

Harris, John. 2010. Enhancing evolution: The ethical case for making better people. Princeton University Press.

Hogan, Richard \& John M. Levoir. 1985. Covenant of love. Pope John Paul II on sexuality, marriage, and family in the modern world. New York: Doubleday and Co.

John Paul II. 1981. Original unity of man and woman. Catechesis on the book of genesis. Boston, MA: St. Paul Editions.

John Paul II. 1994. Letter to families. Gratissimam sane. Retrieved January 18 (1994): 2015.

John Paul II. 1995. Evangelium vitae. Origins 24(42):689-691.

John Paul II. 1997. The theology of the body: Human love in the divine plan. Boston: Pauline Books \& Media.

John Paul II. 2006. Man and woman He created them: A theology of the body. Pauline Books \& Media.

Kock. Tom. 2020. Transhumanism, moral perfection, and those 76 trombones. The Journal of medicine and philosophy: a forum for bioethics and philosophy of medicine 45(2):179-192. US: Oxford University Press. https://doi.org/10.1093/jmp/jhz040.

Kurzweil, Ray. 2006. Reinventing humanity: the future of machine-human intelligence. The futurist 40(2):39-46.

Labrecque, Cory Andrew. 2017. The glorified body: corporealities in the catholic tradition.” Religions 8(9):166. https://doi.org/10.3390/rel8090166.

Lewis, Clive Staples. 1943. The abolition of man: Reflections on education with special reference to the teaching of English in the upper forms of schools. Oxford University Press.

Naam, Ramez. 2005. More than human: embracing the promise of biological enhancement. Broadway Press.

Onishi Bradley. 2011. Information, bodies, and Heidegger: tracing visions of the posthuman. Sophia. 50(1):101-112. https://doi.org/10.1007/s11841-010-0214-4. 
Pope Francis. 2018. Final document of the fifteenth ordinary general assembly of the synod of bishops, 8.

Pope Francis. 2019. Christus Vivit.

Pope John Paul II. 1979. Sign of contradiction. Seabury Press.

Pope John Paul II. 2006. Man and woman He created them: a theology of the body. Translated by Michael Waldstein. Boston: Pauline Books.

Sandberg, Anders. 2013. Morphological freedom - why we not just want it, but need it. The transhumanist reader (pp. 56-64). https://doi.org/10.1002/9781118555927.ch5.

Sandel, Michael J. 2007. The case against perfection. Harvard University Press.

Thomson, Rosemarie G. 2017. Extraordinary bodies: figuring physical disability in American culture and literature. Columbia University Press.

Wareham, Christopher. 2016. The transhumanist prospect: developing technology to extend the human lifespan. The palgrave handbook of the philosophy of aging (pp. 517-538). Palgrave Macmillan, London. https://doi.org/10.1057/978-1-13739356-2_28.

Williams, Bernard. 1973. The makropulos case: reflections on the tedium of immortality. Problems of the self (pp. 82-100). Cambridge: Cambridge University Press. https://doi.org/10.1017/CBO9780511621253.008.

Wojtyla, Karol. 1978. Subjectivity and the irreducible in man. Analecta Husserliana 7:107-114. Edited by Anna-Teresa Tymieniecka. Dordrecht, Holland/Boston, USA: D. Reidel Publishing Company.

Wojtyla, Karol. 1979. The acting person. Translated by A. Potocki (Dordrecht/Boston: D. Reidel Publishing Company.

Wojtyla, Karol. 1981. Love and responsibility. Translated by H. Willetts (New York: Farrar, Straus, Giroux.

World Transhumanist Association. 2002. The transhumanist declaration. 